удК 349.6

DOI https://doi.org/10.32837/apdp.v0i83.141

B. В. Шеховиов

\title{
ФІЛОСОФСЬКО-ІСТОРИЧНІ АСПЕКТИ ТРАНСФОРМАЦІЇ СУСПІЛЬНОЇ СВІДОМОСТІ ЩОДО ТВАРИННОГО СВІТУ ЯК ОБ'СКТА ЕКОЛОГІЧНОГО ПРАВА
}

Постановка проблеми. Фауна є важливим регулювальним і стабілізаційним компонентом біосфери, що охороняється й раціонально використовується для задоволення духовних і матеріальних потреб громадян. Крім релігійного та культурного аспектів, з давніх часів тваринний світ був предметом господарського інтересу людей, об'єктом мисливського і рибного промислу, джерелом промислової, технічної, лікарської сировини, що викликає необхідність розглянути його представників як з об'єктної точки зору, так і квазісуб'єктної.

Наділення тварин правами набуває все більшого поширення у сучасному світі і знаходить своє відображення у працях багатьох дослідників, переважно іноземних. У вітчизняній науці цей сегмент наукової думки знаходиться у зачатковому стані і тому потребує дослідження.

Аналіз останніх досліджень і публікацій. Теоретичною базою дослідження виступили праці вітчизняних та зарубіжних фахівців у галузі екологічного права і філософських наук: В.Є. Борейко, В.В. Петрової, П. Тихого, П. Сінгера, Р. Неша, К. Стоун та інших.

Окремими аспектами, присвяченими регулюванню фауністичних правовідносин, дослідженнями особливих ознак тваринного світу займалися відомі українські та зарубіжні вчені В.І. Андрейцев, А.П. Гетьман, I.І. Каракаш, О.С. Колбасов, С.С. Константініді, С.М. Кравченко, В.В. Костицький, Н.Р. Малишева, В.Л. Мунтян, І.М. Перчеклій, В.К. Попов, С.В. Размєтаєв, П.В. Тихий, В.С. Шахов, Ю.С. Шемшученко, М.В. Шульга та інші.

Невирішені раніше проблеми. У вітчизняній науці повного комплексного теоретичного дослідження таких об’єктів екологічного права як тварини не проводилось. Крім того не було здійснено міжгалузевого аналізу статусу представників фауни. Здебільшого інтерес науковців у сфері екологічного права викликають проблеми правового регулювання суто об'єктів тваринного світу, а не тварин як об'єктів цивільних прав. За таких обставин, багато теоретичних та практичних питань залишається без відповіді, ті чи інші аспекти правового регулювання в цій сфері досліджені поверхнево або взагалі не розглядалися.

Метою статті є дослідження в історичній ретроспективі ставлення людського суспільства до тваринного світу, його вплив на формування культурних та ідеологічних уявлень людей, проведення аналізу наукових концепцій, щодо можливості визнання тварини суб'єктом прав та доречність законодавчого закріплення цього у сучасних реаліях.

Виклад основного матеріалу дослідження. Для формування глибинного уявлення про тваринний світ як об'єкт екологічного права та осмислення його багато-

(C) В. В. Шеховцов, 2019 
гранності необхідно вивчити філософські та тісно з ними пов'язані культурно-релігійні аспекти трансформації суспільної свідомості як основоположні чинники становлення теперішнього та формування майбутнього статусу тварин.

Оскільки древні люди, що жили в гармонії з природою, відчували свою близькість із тваринами набагато гостріше, ніж сучасники, то богів вони уявляли собі не тільки у вигляді людей, а й у вигляді тварин. 3 дерева або з каменю люди вирізали грубе зображення людини або тварини і вважали, що бог вселяється в цього ідола. Мисливці просили у богів удачу на полюванні, рибалки - тихої погоди і рясного улову, хлібороби - багатого врожаю [10, с. 72].

Досить цікавоює класифікація форм шанування рослин і тварин, запропонована B.Є. Борейко, які в своїй більшості мають екологічне звучання: 1) тотеми; 2) духи-господарі; 3) духи-покровителі (таємні союзи); 4) культ предків у вигляді тварин і рослин; 5) священні тварини і рослини. При цьому остання форма шанування - найвища [7, с. 53].

Протягом усієї своєї історії життя людина була нерозривно пов'язана з тваринами найтіснішим чином i, більш того, певною мірою залежала від них. Тварини слугували для людини джерелом їжі і одягу. Тварини попереджали про небезпеку, пророкуючи своєю поведінкою різноманітні зміни в навколишньому світі: шторму і бурі, повені, землетруси, виверження вулканів.

3 прирученням тварин у побуті стародавньої людини відбулися великі зміни. Тому в багатьох місцях стали шанувати бика, або тільця, як божу силу, уявляючи собі, що божество вселяється в цю могутню і благодійну тварину. Наприклад, в Мемфісі і Геліополі - древніх столицях Єгипту - шанували священних биків Апіса і Мневіс. У Саккарі є некрополь священних птахів - ібісів [11, с. 23].

На зорі розвитку людства тварини слугували людині об'єктами для наслідування і шанування та не були для нього «братами меншими». Пам'ятки матеріальної культури епохи Стародавнього Світу: велика кількість скульптур і інших творів образотворчого мистецтва, що дійшли до нашого часу, стародавній живопис, представлений головним чином як розпис на стінах гробниць і храмів, на яких майстри-художники зображували міфологічні та побутові сцени, твори давньогрецьких письменників історіографів, а також результати багаторічних досліджень в етнографічній науці дозволяють говорити про те, що позиція ненасильства відносно тварин існувала ще з давнини. Спочатку вона виявлялася на несвідомому рівні в шануванні тварин, перш за все, в присвоєнні тваринам статусу «священні тварини» [10, с 76].

Питання ставлення до тварин, в тому числі захисту наданих їм прав, було продиктоване не лише турботою про них або бажанням поліпшити свою карму, як, наприклад, у країнах Стародавнього Сходу, а й усвідомленням людиною благотворного впливу гуманного поводження 3 тваринами на моральний стан соціуму. Ціла плеяда релігійних і філософських видатних особистостей - Піфагор Самоський, Діоген, Порфірій, Горацій, Овідій, Сенека та інші - висловлювалася про необхідність поваги до тварин, неприпустимість жорстокості до них.

Цікавим у контексті дослідження є питання правового статусу тварин та теорії визнання їх квазісуб'єктами. Незважаючи на те, що законодавчо тварина безапеляційно віднесена до об'єктів права, дискусійні питання щодо можливості наді- 
лення її певним обсягом правоздатності так чи інакше акцентуються при характеристиці тварини в праві.

3 найдавніших часів тварин сприймали саме як об'єкт, над яким людина могла панувати та користуватися ним. Це було наслідком не обмеженого розуміння їхніх пізнавальних та чуттєвих можливостей, а скоріше спиралося на усвідомлення, що без експлуатації тварини людина не зможе забезпечити власний розвиток. Тобто первісні уявлення про тварини базувалися не на принциповому неправильному уявленні про їхні можливості, а на простому, але потужному твердженні, що виживання та прогрес людської цивілізації безпосередньо залежали від одомашнення та використання тварин. Протягом тривалого періоду історії в різних народах та культурах ставлення до тваринного світу, в тому числі в правовому аспекті, зазнавало різних деформацій, змінювалося залежно від змін в основоположних підвалинах життя та еволюції людської свідомості, призводячи часом до докорінної трансформації соціальних інститутів [5].

Для того, щоб на належному рівні здійснити оцінку зазначених позицій та встановити перспективи сучасних реформ, необхідно перш за все дослідити історично сформовані правила, які складали фауністичне право.

За традиційними концепціями фауністичного права тварини зазвичай розглядалися як об'єкти прав, наданих їх власникам, але не як власники прав людини. Проте, навіть як об'єкти тварини історично займали значиме місце в загальній системі правових та соціальних відносин. Тварини в минулому представляли значно більшу частку суспільного багатства, ніж сьогодні.

Як зазначає Джаред Даймонд, великі домашні тварини мали вирішальне значення для тих людських об'єднань, які ними володіли, адже вони забезпечували м'ясом, молочними продуктами, добривами, наземним транспортом, шкірою, плуговою тягою та вовною. Дрібніші тварини, такі як птахи, також були одомашнені задля їх м'яса, яєць та пір'я. У господарствах, у яких не вистачало механічних чи електричних джерел живлення, тяглові тварини розглядалися не лише як джерела їжі, але часто були предметами капіталу нарівні з землею і рабами [3].

Обгрунтування правового становища тварин деякими прогресивними вченими не може спиратися на сумнівне припущення, що нове розуміння тварин виправдовує перегляд старих правових устоїв. Стародавні люди, можливо, мало що знали про тонкощі поведінки тварин, та все ж їх розуміння особистості тварини, їх розуміння схильностей та психічних станів, їхніх навичок одомашнення, спростовує те, що вони мали труднощі у відрізненні тварин від неживих предметів.

Сучасні дискусії про тварин виходять за рамки попередніх історичних аргументів. При вирішенні цієї суперечки деякі дослідники використовують тісний зв'язок між рабами і тваринами в стародавньому світі. Зважаючи, що несправедливість відносно рабів повинна бути порівнянна з несправедливістю відносно тварин. Таким чином, Стівен Уайз починає зі спостереження, що Аристотель об'єднував тварин із рабами і жінками як істотами, які були нижче, ніж грецькі чоловіки в соціальній ієрархії. Він зазначає, що Аристотель зауважив, що «бик - це раб бідної людини». Тепер, коли виплавлені помилки, пов'язані з рабами і жінками, необхідно виправити людську несправедливість відносно тварин [5]. Проте, навіть до змі- 
ни, з плином часу, формального юридичного статусу було б помилкою припускати, що з рабами поводилися як з вільними жінками і що до тварин ставилися так само.

Усунення спочатку рабства, а потім громадянської недієздатності для жінок відбулося задовго до нинішньої агітації за зміну статусу тварин. Природні когнітивні й емоційні обмеження тварин, навіть вищих тварин, виключають будь-яке створення повного паритету. Якій тварині може бути надано право на укладення договору, для надання свідчень у суді, право голосувати на виборах, брати участь у політичних дискусіях? Ніщо з цього не має ніякого сенсу через відсутність внутрішніх здібностей тварин.

Захист від фізичного насильства, або, можливо, дещо ширше право, відповідно до якого тварини не можуть бути використані в якості ресурсів, право не розглядатися як речі, що належать людям - це допустимий максимум [14, с. 8].

Професор філософії Гарвардського університету Роберт Нозік приділяє багато уваги цьому питанню. Його спосіб аргументації працює наступним чином. Спочатку він розвиває тему моральних побічних обмежень, які відображують наше роздільне існування, роблячи висновок що не може бути виправданою жертва одних 3 нас заради інших. Це розуміння призводить швидше до либертаріанської сторони обмеження проти агресії. Щоб з'ясувати, наскільки сильне це обмеження, Нозік звертається до моральних побічних обмежень, які повинні бути встановлені в силу того, що тварини є розумними істотами.

3 іншої точки зору розглядає це питання Стівен Уайз, використовуючи теорію пізнання та висуваючи твердження про те, що обмежені пізнавальні здібності підтримують твердження про негативні права, що права не повинні використовуватися в якості факторів для людської переваги [5].

«Звільнення тварин» Пітера Сінгера, наприклад, спростовує твердження Декарта про те, що у тварин немає інтересів, тому що вони не розумні. Філософ стверджує, що інтереси людей і тварин повинні враховуватися однаково з моральної точки зору, тому що обидва мають здатність страждати, зазнавати болю і відчувати задоволення [4, с. 13].

Р. Неш, використовуючи різноманітні аргументи від філософських до політичних, у своїй роботі намагається довести думку про те, що дика природа (у тому числі тварини) повинна мати моральні права на життя, свободу та щастя. Зокрема, дика тварина повинна мати право на життя, право на свободу від людського втручання, право на захист від непотрібного страждання, право на продовження життя, право на здорову зону проживання, право на прагнення до щастя, право на реалізацію еволюційного потенціалу тощо [11, с. 5].

Віднайшло філософське осмислення і питання класифікації тварин у категорії власності. Тварини юридично класифікуються як власність у більшості країн світу - це спадщина давніх систем права. Однак з тих пір наукові, філософські та культурні уявлення про тварин змінилися, тож має сенс переглянути доцільність їх майнового статусу.

На думку деяких дослідників сучасності, обгрунтування для класифікації тварин як власності є слабким, і тому необхідно розпочати діалог про альтернативні варіанти їх правового статусу. Прихильники цієї концепції стверджують, що сам 
факт того, що тварина біологічно не належить до людського виду, не перешкоджає тому, щоб її класифікували як суб'єкт права. Ряд країн фактично почали вивчати цю можливість. Зокрема, в деяких місцевостях робилися спроби вирішити проблеми, пов'язані з класифікацією тварин як майна шляхом створення для них окремого правового статусу.

Цивільні кодекси Австрії, Німеччини та Швейцарії містять положення, які безпосередньо відносяться до правового статусу тварин. Наприклад, стаття 285 Цивільного кодексу Австрії, яка почала діяти в 1988 році, передбачає, що «тварини не є об'єктами, вони захищені спеціальними законами». Крім того, він передбачає, що закони, які стосуються об’єктів, «не застосовуються до тварин, якщо немає суперечливих положень». Аналогічні положення існують у Цивільних кодексах Німеччини та Швейцарії $[1,2]$. Хоча на перший погляд ці положення змінили правовий статус тварин у цих країнах, однак це не зовсім так. Хоча ці положення змінили ступінь, в якому тварини підкоряються закону про об’єкти, вони не зайшли так далеко, щоб віднести тварин до категорії «осіб» .

Зокрема стаття 641а Цивільного кодексу Швейцарії створила окрему категорію для тварин, відмінну від предметів і людей. Тобто тварини більше не є об'єктами, але вони не є і носіями прав. Новий закон встановлює, що тварини більше не є об'єктами. Очевидною є відсутність визначення, яке роз'яснює їх конкретний правовий статус. Незважаючи на те, що намір законодавця полягав у тому, щоб поліпшити правовий статус тварин, більшість «спеціальних правил», що стосуються тварин в першу чергу поліпшують правове становище власника або зберігача тварини, а не їі самої. Стаття 641а носить переважно декларативний характер, введення окремої правової категорії для тварин ніколи не передбачалося [5].

Хоча в цих положеннях йдеться, що закон про об'єкти не застосовується до тварин, для яких існують особливі закони, посилаючись на закони про захист тварин, вони допускають застосування законів про власність, якщо відповідного закону про тварин не існує. Іншими словами, якщо немає законів, що регулюють відносини людини з тваринами, то тварини продовжують підкорятися закону об’єктів. Тварини, таким чином, не набули правосуб'єктності і не отримали людей, які доглядають за ними або опікунів замість власників. Закон говорить, що вони більше не є об’єктами, але в більшості випадків вони все ще розглядаються як такі.

Інші підходи до зміни правового статусу тварин шляхом судового втручання використовуються в ряді інших країн, в тому числі в Румунії, США і Аргентині. У 2013 році Проект по захисту прав тварин “Nonhuman Rights Project” подав до суду Нью-Йорка від імені Томмі клопотання про видачу наказу habeas corpus щодо шимпанзе, якого тримають у неволі. Щоб отримати цей наказ, важливо довести, що позивач є суб’єктом права. На підтримку своєї петиції були представлені письмові свідчення експертів, які доводять, що шимпанзе мають складні когнітивні здібності, які задовольняють вимогам загальноприйнятої концепції особистості і з цього випливають його права на захист від тілесних ушкоджень.

Суд відхилив доводи NhRP, і судовий наказ був відхилений. Два аналогічних клопотання були зроблені від імені трьох інших шимпанзе, яким також було відмовлено. Апеляції були подані до Апеляційного відділу Верховного суду штату 
Нью-Йорк в усіх справах. У справі Томмі апеляційний суд, що складається з п'яти суддів, відхилив апеляцію на тій підставі, що право на свободу не доступне особі, яка не здатна брати на себе обов’язки і відповідальність [6, с. 79].

Незважаючи на особливе загострення цього питання в останні роки, проблема визнання тварини суб'єктом правовідносин не є принципово новою для світової та вітчизняної науки. Ще наприкінці XIX сторіччя Я.А. Канторовичем була підготовлена монографія «Процессы против животных в средние века». У науковій праці тварина виступає суб'єктом відповідного процесу (цивільного або кримінального), може бути прирівняна до суб'єкта права. Як зауважує автор, вперше судові процеси проти тварин зустрічаються у XIII сторіччі, хоча, вочевидь, вони мали місце й раніше, але в архівах не залишилось документального підтвердження цьому $[12$, c. 4]. В Україні, на території Карпат, існували суди над ведмедями, тобто ведмідь знову ж таки фактично визнавався суб'єктом правовідносин [8, с. 72].

Відповідно до сучасної вітчизняної правничої позиції, тварини суб'єктами права бути не можуть. Не змінює цього й норма про заповідальне покладання на одного або декількох спадкоємців обов'язку утримувати домашніх тварин, які належали заповідачеві, а також здійснювати необхідний нагляд і догляд за ними. Юридична енциклопедія в якості суб'єкта права визначає фізичну або юридичну особу, яка є учасником національних чи міжнародних правовідносин [15, с. 138]. Енциклопедія цивільного права України, в свою чергу, деталізує, що суб'єктами цивільного права є фізичні особи, юридичні особи та публічно-правові утворення [9, с. 216]. Тобто, тварина до переліку суб'єктів цивільного права не відноситься й у статусі учасника цивільно-правових відносин перебувати не може. Наприклад, як вже зауважувалось вище, тварина не може бути учасником спадкового правовідношення, а може бути тільки частиною спадкової маси, яка підлягає належному догляду.

Інколи на теренах науково-публіцистичного інформаційного простору висловлюється думка про захист прав тварин, а отже, й визнання за тваринами відповідних прав внаслідок прийняття Верховною Радою України Закону України «Про захист тварин від жорстокого поводження» [13]. Втім, імплементація у сучасні реалії означеного нормативно-правового акту пролобійована скоріш загально гуманістичною спрямованістю права та намаганням зміцнити засади моральності у суспільстві. Самі норми Закону України «Про захист тварин від жорстокого поводження» [13] уникають навіть натяку на можливість застосування формулювання «право тварини на...».

Висновки. Як показує проведене дослідження, правове становище тварин не завжди й не у всіх правових системах отримувало сталий статус об'єкта правовідносин. Окремі ознаки, що вирізняли їх із загального кола правових об'єктів, тією або іншою мірою проявлялися у різноманітних джерелах протягом досить довгих історичних періодів. Сьогодні ці процеси розгортаються з новою силою: зоозахисники у США мають можливість подавати від імені тварин позови до суду, у деяких штатах США вони можуть бути носіями авторських прав, країни східного світу встановлюють особливий статус для дельфінів, корів, панд.

Розвиток суспільної свідомості різних держав, готовність соціуму до локальних перетворень перебуває на різних рівнях, навіть незважаючи на сучасний стан 
інформатизації й посилені процеси гармонізації. Сучасній українській правовій сфері не притаманні тенденції до змінювання чи корегування статусу таких об'єктів прав як тварини, однак, прогностична функція права одним із своїх основних призначень як раз то і має створення умов для формування нових, зумовлених реаліями людського буття і економіки відносин. Більшою мірою найбільш раціональним варіантом вирішення обговорюваної дискусії вважають збереження поточного статус-кво тварин. За переважаючою думкою вони виключаються з числа суб'єктів права в силу відсутності у них здатності до розумного мислення. Однак випадки вчинення дельфінами та китами суїцидів навряд чи можна однозначно вважати просто збоями їх геомагнітних компасів. Безумовно, цей момент є дуже дискусійним, але можливий і розвиток інших правовідносин у майбутньому. Наявність же у тварин ознак, що виділяють їх із ординарного розуміння об’єкта правовідносин, притаманність їм атрибутів квазісуб'єктності є цілком допустимим.

\section{Jimepamypa}

1. Austrian Civil Code, art 285, Adopted on 1811. URL: https://www.jusline.at/gesetz/abgb/ paragraf/285a.

2. German Civil Code $\S 90$ a Adopted on 2 January 2002. URL: https://www.gesetze-im internet.de/ englisch_bgb/englisch_bgb.html\#p0272.

3. Jared Diamond, Guns, Germs and Steel: The Fates of Human Societies Human Ecology Review, Vol.14,No.2, 2007.URL:https://www.humanecologyreview.org/pastissues/her142/yorkandmancus.pdf.

4. Peter Singer, Animal Liberation (Harpercollins, revised ed, 2002), 10-15.

5. Richard Epstein. Animals as Objects, or Subjects, of Rights, in Cass R Sunstein and Martha C Nussbaum (eds), Animal Rights: Current Debates and New Directions (Oxford University Press, 2004) 143. URL: https://papers.ssrn.com/sol3/papers.cfm?abstract_id=359240.

6. Robert Garner "Political Ideology and the Legal Status of Animals" (2002) 8 Animal Law 79-80. URL: https://www.tier-im-fokus.ch/wp-content/uploads/2009/09/garner02.pdf.

7. Борейко В.Е. Экологические традиции, религиозные воззрения славянских и других народов. Т. 1. К. : Киевский эколого-культурный центр, 2003. 160 с.

8. Васидлов Ю. Українське народне коріння концепції прав природи. Закон «Про захист тварин від жорстокого поводження». Український прорив. К. : Київський екологокультурний центр, $2007.88 \mathrm{c}$.

9. Енциклопедія цивільного права України. відп. ред. Я.М Шевченко; Ін-т держави і права ім. В.М. Корецького НАН України. К. : Ін Юре, 2009. 952 с.

10. Капытина Т.П. Защита животных в эпоху Древнего Мира. Вопросы исторической науки: материалы III Междунар. науч. конф. (Москва, январь 2015 г.). М. : Буки-Веди, 2015. С. 69-78. URL: https://moluch.ru/conf/hist/archive/128/7034.

11. Нэш Р. Права природы. История экологической этики. К. : Киевский эколого-культурный центр, 2001. $166 \mathrm{c}$.

12. Канторович Я. Процессы против животных в средние века. Санкт-Петербург : Юрид. б-ка, ценз. $1897.58 \mathrm{c}$.

13. Про захист тварин від жорстокого поводження: Закон України від 21.02.2006 № 3447-IV. Голос України. 2006. 05 трав. (№ 82).

14. Сингер П. Человек и животное равны. Гуманитарный экологический журнал. 2003. Т. 5. Спецвыпуск. С. 8-9.

15. Юридична енциклопедія: в 6 т. ред. кол. Ю.С. Шемшученко та ін. К. : Укр. енцикл., 1998. T. : A-Г. $672 \mathrm{c}$. 


\section{Анотація}

\section{Шеховцов В. В. Філософсько-історичні аспекти трансформації суспільної свідомості щодо} тваринного світу як об'єкта екологічного права. - Стаття.

У статті автором досліджено окремі правові та філософські аспекти становлення підходів до загального розуміння тварин як об’єктів правовідносин, випадки наділення їх за окремих соціально-історичних періодів додатковими якостями, що виходять за межі вчення про об'єкти прав.

Незважаючи на те, що законодавчо тварина безапеляційно віднесена до об'єктів права, дискусійні питання щодо можливості наділення їі певним обсягом правоздатності так чи інакше акцентуються при характеристиці тварини в праві.

Встановлено, що за традиційними концепціями фауністичного права тварини зазвичай розглядалися як об'єкти прав, наданих їх власникам, але не як власники прав людини. Проте, навіть як об'єкти тварини історично займали значиме місце в загальній системі правових та соціальних відносин. Тварини в минулому представляли значно більшу частку суспільного багатства, ніж сьогодні.

Віднайшло філософське осмислення і питання класифікації тварин в категорії власності. Тварини юридично класифікуються як власність у більшості країн світу - це спадщина давніх систем права. Однак $з$ тих пір наукові, філософські та культурні уявлення про тварин змінилися, тож має сенс переглянути доцільність майнового статусу тварин.

Дослідження показує, що на думку деяких дослідників сучасності обгрунтування для класифікації тварин як власності є слабким, і тому необхідно розпочати діалог про альтернативні варіанти їх правового статусу. Прихильники даної концепції стверджують, що сам факт того, що тварина біологічно не відноситься до людського виду, не перешкоджає тому, щоб її класифікували як суб'єкт права.

Досягнуто висновку, що відповідно до сучасної вітчизняної правничої позиції, тварини суб'єктами права бути не можуть. І сьогодні сучасній українській правовій сфері не притаманні тенденції до змінювання чи корегування статусу таких об'єктів прав як тварини, адже за переважаючою думкою вони виключаються з числа суб'єктів права в силу відсутності у них здатності до розумного мислення. Разом із тим, наявність у тварин ознак, що виділяють їх із ординарного розуміння об'єкта правовідносин, притаманність їм атрибутів квазісуб'єктності є цілком допустимим.

Ключові слова: фауна, тваринний світ, об'єкт екологічного права, квазісуб'єкт, тварини як суб'єкти, правоздатність тварин, філософський аналіз правового статусу тварин.

\section{Summary}

Shehovtsov V.V. Philosophical and historical aspects of the transformation of public consciousness in relation to the animal world as an object of environmental law. - Article.

The article explores the specific legal and philosophical aspects of the formation of approaches to the general understanding of animals as objects of legal relations, the cases of their granting in certain socio-historical periods additional qualities that go beyond the doctrine of the objects of rights.

Despite the fact that the animal is legally referred to as objects of law, debatable questions about the possibility of granting it a certain amount of legal capacity in one way or another are emphasized when characterizing the animal in law.

It has been established that under traditional concepts of faunistic law, animals are usually regarded as objects of rights conferred on their owners, but not as holders of human rights. However, even as animal objects, historically they have occupied a significant place in the overall system of legal and social relations. Animals in the past represented a much larger share of public wealth than today.

It is concluded that with philosophical thinking and questions about the classification of animals in the property category. Animals are legally classified as property in most countries of the world - a legacy of ancient systems of law. However, since then scientific, philosophical and cultural ideas about animals have changed, so it makes sense to review the appropriateness of the property status of animals.

The study shows that, according to some researchers, the rationale for classifying animals as property is weak, and therefore a dialogue on alternative options for their legal status is needed. Proponents of this concept argue that the mere fact that an animal is not biologically related to the human species does not prevent it from being classified as a subject.

It is concluded that, according to the current domestic legal position, animals cannot be eligible. Even today, the current Ukrainian legal sphere does not tend to change or adjust the status of such objects of rights as animals, because they are overwhelmingly excluded from the rights of subjects because of their lack of reasoning ability. However, the presence of features in animals that distinguish them from the ordinary understanding of the object of the relationship, the inherent attributes of quasi-personality attributes is quite acceptable.

Key words: fauna, animal life, environmental law object, quasi-entity, animals as subjects, animal legal capacity, philosophical analysis of the legal status of animals. 